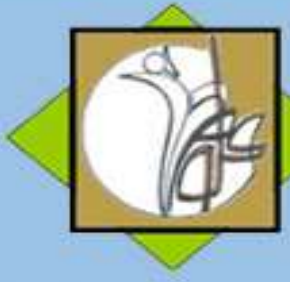

\author{
Research Article
}

\title{
Examining the Motivational Barriers to Youth Sport: A Qualitative Study
}

\author{
Ghasem Babaei Zarch ${ }^{1}$, Hamid Salehi
}

1. Ghasem Babaei Zarch, (MA) University of Isfahan, Isfahan, Iran

2. Hamid Salehi, (Ph. D) University of Isfahan, Isfahan, Iran

\section{ARTICLE INFO}

Received October 2017

Accepted July 2018

\section{KEYWORDS:}

Qualitative Research, Coach, Parents, Youth Sport

\section{CITE:}

Babaei-Zarch G, Salehi H. Examining the Motivational Barriers to Youth Sport: A Qualitative Study, Research in Sport Management \& Motor Behavior, 2020: 10(20):

63-79

\section{ABSTRACT}

Identifying motivational barriers to sport participation in children and adolescents is important for engaging them in sport activities. The aim of this qualitative study was to explore perceptions of children and adolescents, parents, and sport coaches about barriers of youth sport participation. Semistructured interviews were conducted with 12 children and adolescents, 8 parents, and 5 coaches. Content analysis was employed to analysis the transcripts. The results of the data analysis yielded some themes as the motivational barriers to participation in sport by children and adolescents that were grouped into two domains: the personal and the environment barriers. Constituent themes in the personal barrier's domain included: the lack of having sport talent and lack of progression in sport, not pleasuring from participation in sport, and sport related injuries. Constituent themes related to the environmental barrier's domain included: lake of sports culture, lake of facilities, economic problems, not being supported, and not having future. This qualitative study provided a deeper understanding about motivational barriers for habituation to sport in children and adolescents. The themes would lead youth sports organizers, parents, and coaches to motivate youth to participate and endure in sport activities by changing the personal and environmental factors. 


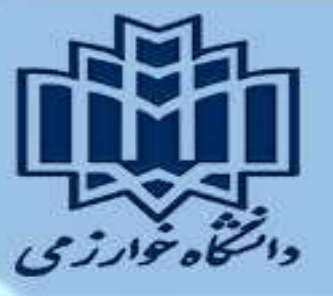

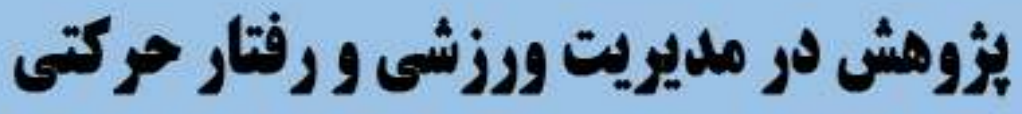

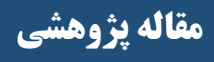

\section{بررسى موانع انكيزشى ورزش كودكان و نوجوانان: يك يثوهش كيفى}

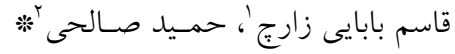

ا.كارشناسى ارشد روانشناسى ورزشى، دانشكدة علوم ورزشى دانشكاه اصفهان، اصفهان، ايران

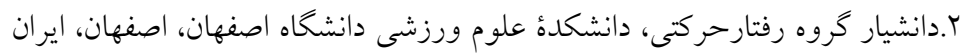

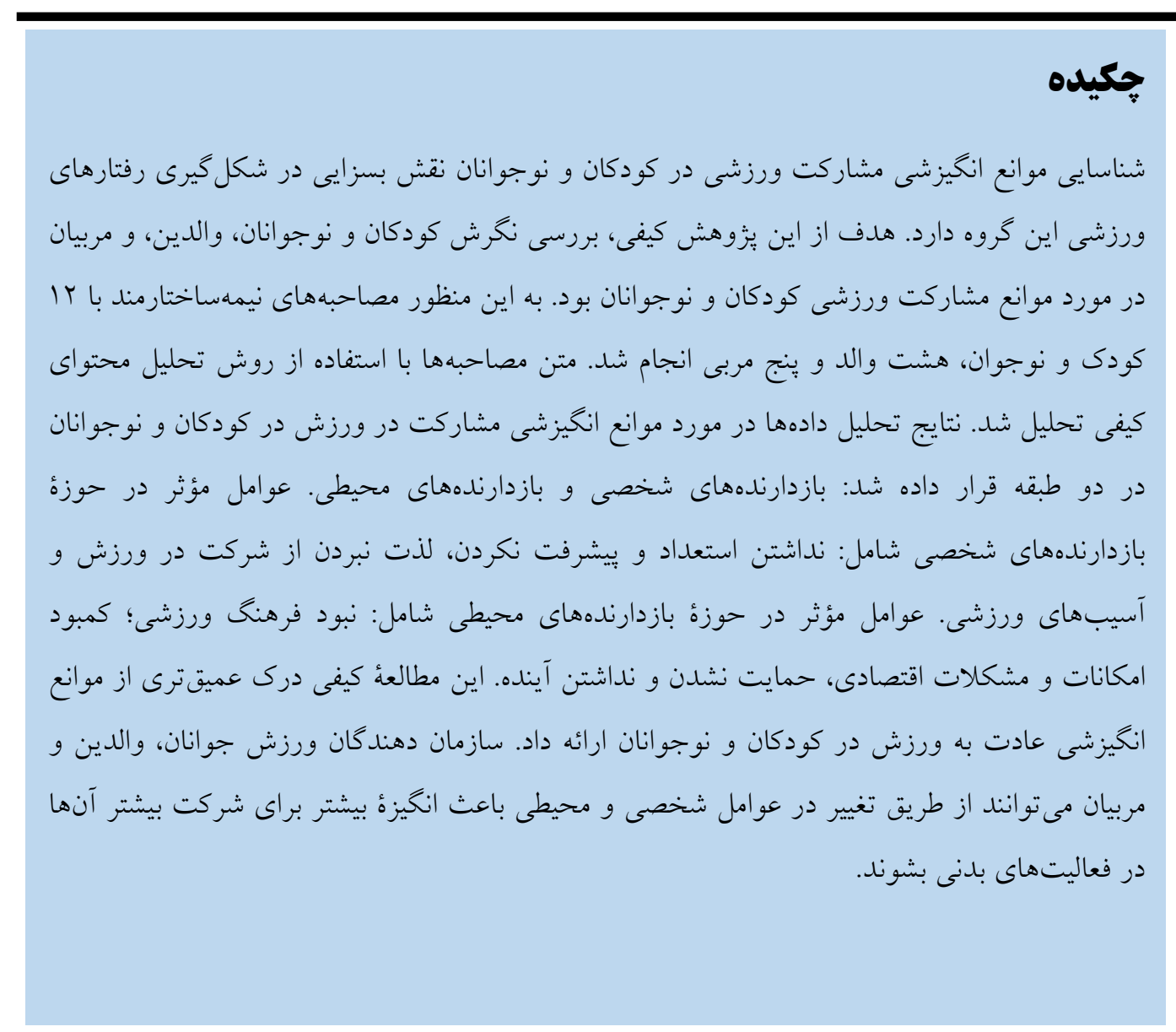

اطلاعات مقاله:

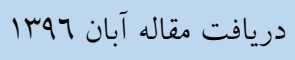

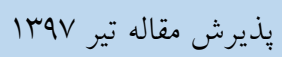

ثقونسنده مسئول:

salehi@spr.ui.ac.ir

وازةه هاى كليدى:

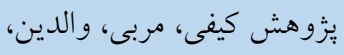

ورزش كودكان و نوجوانان.

إرحاع:

بابايىزارج ق، صالحى ح. بررسى

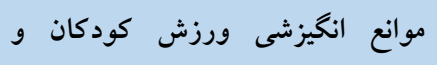

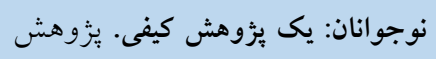
در مديريت ورزشى و رفتار حركتى،

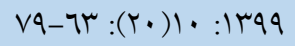




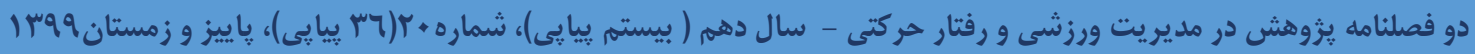

مقــلdه

امروزه ورزش بهعنوان يك يديدهُ اجتماعى در دنيا و ازجمله در كشور ما يذيرفته شده است. در حال حاضر فعاليت بلنى

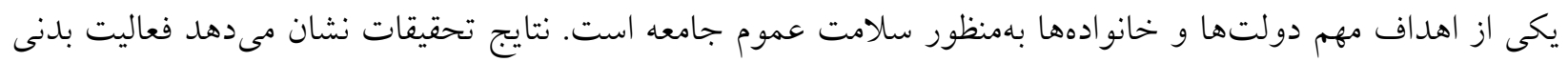
در كودكان و نوجوانان مىتواند با منافع سودمندى همجيون بهبود عزت نفس، تعامل اجتماعى، كاهش علائم افسردگى و بهبود سلامت روانى - اجتماعى همراه باشد (1). همجنين، مقدار ناكافى فعاليت بدنى در كودكان و نوجوانان بهعنوان يك عامل مهم در كمك به جاقى و بيمارىهاى همه گير شناخته شده است (Y). محققان توصيه مىكنند كودكان و نوجوانان بايد روزانه بهطور متوسط به ميزان •7 دقيقه يا بيشتر در فعاليت بدنى متوسط تا شديد شركت كنند (r). تحقيقات نشان داده است تعداد زيادى از كودكان و نوجوانان بهدرستى و در سطوح كافى از فعاليت بدنى شركت نمى كنند تا به اين منافع دست يابند (ع). مطالعات تعدادى از عواملى كه باعث بى انخيز گى در كودكان و نوجوانان نسبت به فعاليت بدنى مى شود را شناسايى كرده است؛ كه ازجملةُ آن مىتوان به ترويج رقابت در تيم توسط مربيان (0)، جلسات مربيخرى بيشازحد جدى با تأكيد بر برنده شدن بهوسيلهُ والدين، مربيان و همسالان (7)، قضاوت كردن كودكان در يكى محيط رقابتى و درنتيجه ترس از شكست به علت ارزيابى در برابر همسالان (V) و عدم وجود لذت (N) اشاره كرد.

برخى يزوهشها بعضى از عوامل بازدارنده مشاركت ورزشى را به شيوههاى مختلف شناسايى كردهاند (9). بهعنوانمثال حسينى، انوشه، عباسزاده و احسانى (•l) در يزوهش خود به بررسى موانع عادت به ورزش در دختران نوجوان برداختند. اين مطالعه روى دختران نوجوان •l تا 19 سال شهر تهران و به شيوه كيفى انجام شد. آنها

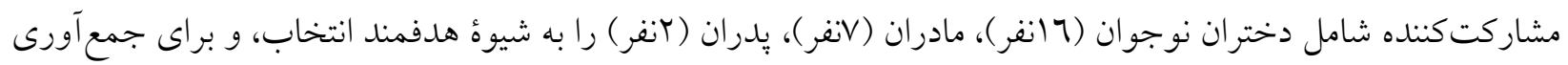
دادهها از مصاحبهُ نيمه ساختارمند استفاده نمودند. براى تجزيهوتحليل دادهها نيز از تحليل محتواى كيفى استفاده شد. يافته هاى اين يزوهش نشان داد موانع عادت به ورزش در دختران نوجوان شامل بازدارندهاى آشكار (موانع مربوط به

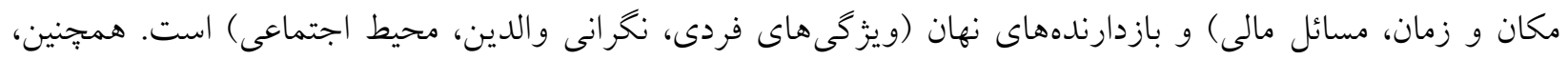
ديكسون (1) در يزوهشى بهمنظور بررسى موانع يا ادامهُ مشاركت ورزشى در دانش آموزان مدرسهاى در آمريكا كه روى ^Yr دانش آموز با دامنهُ سنى 1اتا 10 سال انجام شد، نشان داد دانشآموزان سركرم شدن را دليل اصلى جهت ادامه

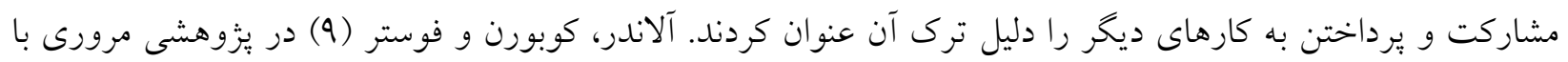
عنوان درى مشاركت در ورزش و فعاليتهاى بدنى در ميان كودكان و بزرگسالان كه مرورى بر يزوهشهاى كيفى بين سالهاى ع 199 تا ع +. r در انحلستان بود به بررسى دلايل مشاركت و عدم مشاركت كودكان و بزرگسالان به انجام فعاليت ورزشى يرداختند. آنها بيان كردند كنترل وزن، تعامل اجتماعى و لذت بردن از رايجترين دلايل جهت مشاركت در ورزش و فعاليت بدنى بود. همجنين انخَيزهُ دختران از مشاركت در ورزش حفظ تناسباندام بود. بهعلاوه جالشهاى هويتى مثل داشتن بدن نامناسب ازنظر ديخران، كمبود اعتمادبهنفس و مهارت نيز از موانع مشاركت بودند. در اين يزوهش انخيزههاى كودكان جهت مشاركت در ورزش شناخت، انجام فعاليتهاى جالشى، حمايت والدين و محيط ايمن بود و موانع شركت 


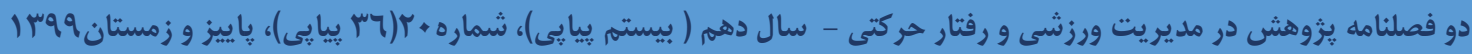

در ورزش و فعاليت بدنى نيز ورزشهاى رقابتى و فعاليتهاى با قوانين و سازمانبندى بالا بود. در يزوهشى ديخر، ويتج،

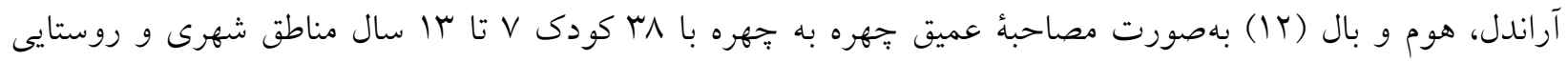
ويكتوريا در استر اليا انجام شد، نشان دادند زمينههايى كه به كودكان كمك مى كند تا سبك زندكى غيرفعال را كنار بحذارند شامل حمايت والدين و تشويق به فعاليت بدنى، داشتن يك محيط فيزيكى حمايتى و داشتن دوستان فعال، فعال بودن بهعنوان اولويت فردى، آكاهى از خطرات بهداشتى و سلامتى مرتبط با رفتار بى تحركى، قوانين والدين و محيط حمايتى خانه است.

علاوه بر خود فرد خانوادهها بهويزه والدين نيز از طريق انواع سازوكارها بر رفتار فعاليت بدنى كودكان نفوذ دارند (r) (1). تحقيقات نشان مى دهد، شركت والدين در فعاليتهاى بلدنى مىتواند سبب افزايش شركت فرزندانشان در فعاليت شود (ع (). براى كودكان، نخرشها و باورهاى والدين نسبت به فعاليت بدنى فرزندانشان و حمايت از آنها مىتوانند تعيين كنندها يا موانع مهمى براى انتخاب سبك زندگى فعال و سالم آنها محسوب شود. والدين (و نيز خواهران، برادران و دوستان) نقش مهمى در كرايش كودكان و نوجوانان به انتخاب سبك زندگى سالم و مبتنى بر فعاليت بدنى منظم دارند. دخالت بيشازحد والدين در ورزش كودكان و نوجوانان مشكلات بسيارى را موجب مىشود، ليكن برنامهاى ورزشى سازمانيافته بدون حمايت والدين تداوم نمى يابند. اين حمايتها مىتواند در قالب كمكهاى والدين، در نقلوانتقال آنها براى مسابقات، كمكهاى مالى و ارائه خدمات ماند مشاركت بهعنوان مربيان داوطلب باشد. در يزوهشها والدين دلايلى مانند، دسترسى نداشتن به امكانات ورزشى در محل، مشكلات رفتو آمد به زمينبازى، بالا بودن هزينهُ استفاده از امكانات ورزشى، امن نبودن محيط خارج از خانه، و نداشتن وقت را بهعنوان موانع موجود بر سر راه حضور فرزندانشان در برنامهاى ورزشى برشمردند (10، 7 (1)). علاوه بر والدين، مربيان نيز جايگاه والايى در برنامههاى ورزشى كودكان و نوجوانان دارند و نقش آنان به حدى مهم

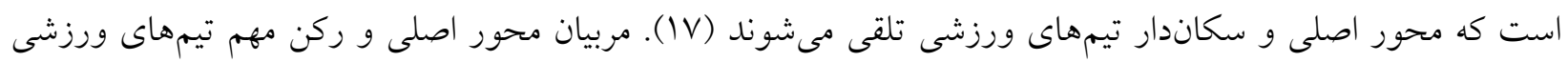

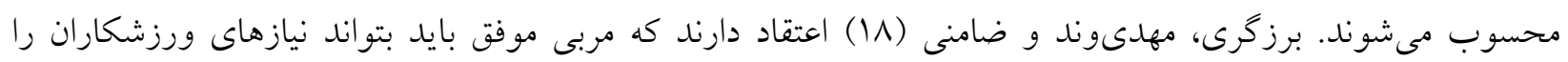
بشناسد و بر اساس امكانات محيطى و فرصتهاى رقابتى، اين گونه نيازها را در جهت افزايش بازدهى فردى و گروهى به

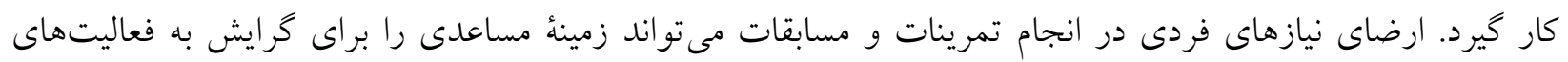

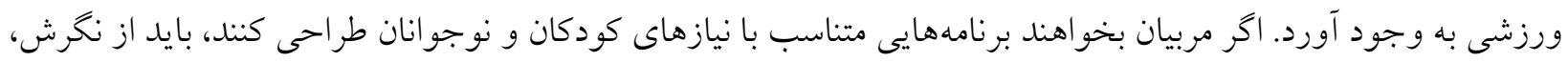
اهداف و عقايد آنان در مورد ورزش شناخت بهترى بيدا كنند. اين واقعيت كاملاً يذيرفته شده است كه فعاليت ورزشى براى عموم مردم لازم و مفيد است. ولى باوجود همهٔ اسناد و مدارى در خصوص ارزش و جايگاه ورزش و تربيتبدنى در توسعه سلامتى و تندرستى، متأسفانه در كشور ما هنوز اهميت و ضرورت ورزش در بين اقشار مختلف جامعه شناختهشده نيست و بسترهاى لازم براى آن فراهم نشده است.

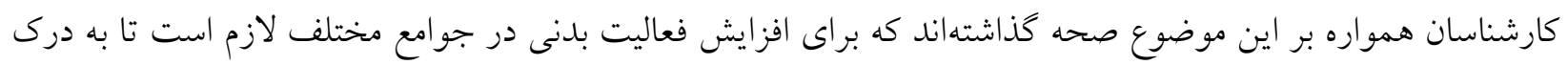




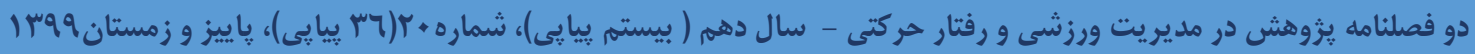

عواملى كه منجر به عدم فعاليت بدنى در كودكان و نوجوانان مى شود براى طراحى مداخلات مناسب يى ببريم. شواهد نشان داده كه بدون مداخلات رفتارى مؤثر، نزديك به •0 درصد افرادى كه برنامهُ فعاليت بدنى را شروع مى كنند بهطور متوسط در عرض 7 ماه فعاليت بلدنى را كنار مى گذارند (19). قرائن حاكى از آن است كه والدين بهخصوص در جوامع توسعهنيافته به دليل شرايط حاكم بر كشور (شرايط اقتصادى و اجتماعى مثل كمبود درآمد، كمبود امكانات، كمبود فرهنگ مطالعه) - بهاستثناى برخى از موارد - در سوق دادن فرزندانشان به ورزش موفقيت كمى داشتهاند. شايد يكى از علل اين امر، عدم آكاهى از موانع، نيازها و نخرش واقعى بمى بهى فرزندان هم ازنظر جسمانى و هم ازنظر روانشناختى نسبت به ورزش و فعاليت بدنى باشد. تحقيقاتى كه تاكنون درزمينهُ ورزش كودكان و نوجوانان انجام شده است، نيز تمايل به بررسى رفتارهاى ورزشى تفريحى يا ورزش مدارس داشته است و يزوهشى كه در آن ورزش قهرمانى مدنظر قرار بخيرد، اندك است. از طرفى، در رابطه با نقش والدين و مربيان بهعنوان واحد ارتقاء دهنده سلامت با تأكيد بر فعاليت بدنى مطالعاتى انجام شده است اما نتايج مختلف و كاه متضادى درزمينهُ تأثيرشان بر فعاليت بدنى كودكان و نوجوانان وجود دارد. بِ با در نظر كرفتن احتمال تأثير والدين و مربيان بر فعاليت بدنى كودكان و نوجوانان، درى جامع و عميق از نحوهُ تأثير آنها بر فعاليت بدنى ورزشكاران جوان ضرورى به نظر مىرسد. كشف اين سازوكار مى تواند به طراحى مداخلات مؤثرتر مبتنى بر والدين و مربيان كمك كند، ضمن اينكه به اين وسيله حوزههاى موردنياز براى تحقيق بيشتر آشكار مىشود. بنابراين، شناسايى موانعى كه بر سر راه مشاركت ورزشى كودكان و نوجوانان وجود دارد، مىتواند كمك شايانى به رفع آنها و ارائهُ راهكارهاى مؤثرى درزمينهُ بالا بردن مشاركت در فعاليتهاى ورزشى نمايد. اكثر تحقيقاتى كه تاكنون

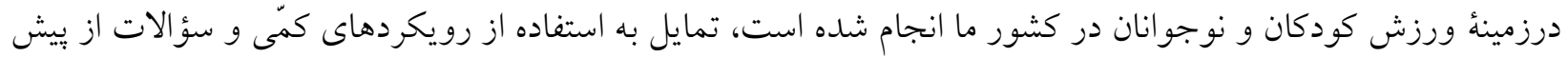
تعيينشده در مورد نخرش و عقايد افراد در مورد ورزش و فعاليتهاى بدنى و درنتيجه توجه كمتر به رويكردهاى كيفى در اين حوزه داشتهاند. بنابراين يك رويكرد جايكزين كه بتواند دلايل را از زبان خود افراد بيان كند ضرورى به نظر مىرسد. همجنين با توجه به سوابق يزٔوهش، مطالعهاى كه در ايران ديدكاه كودكان و نوجوانان، والدين و مربيان را بهطور همزمان موردبررسى قرار دهد مشاهده نخرديد؛ همجنين يُزوهشى كه در آن يسران را مدنظر قرار بدهد كمتر موردتوجه

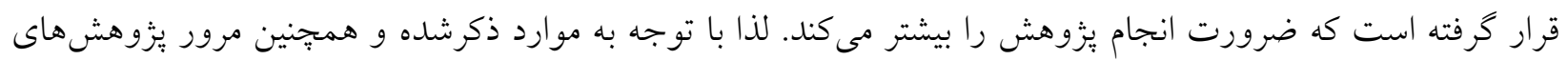
صورت كرفته در اين خصوص اين تحقيق به شيوه كيفى به دنبال ياسخكويى به اين سؤال است كه موانع اصلى گرايش و تداوم ورزشى در كودكان و نوجوانان جيست؟ ديد گاههاى والدين و مربيان در اين زمينه جگگ نه است؟

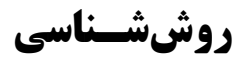

اين مطالعه كيفى و از نوع تحليل محتواست. در راستاى نيل به هدف تحقيق از روش كيفى و مصاحبهُ نيمه ساختارمند كه متمركز بر معانى و تفسيرهاى مشاركت كنند كان در آن است، استفاده شد. با توجه به موضوع تحقيق اين بزوهش اهداف اكتشافى و توصيفى را يوشش مى دهد. بهطورى كه محقق در راستاى انجام اين بخش به دنبال كشف ديدكاههاى مختلف

https://jrsm.khu.ac.ir/ 


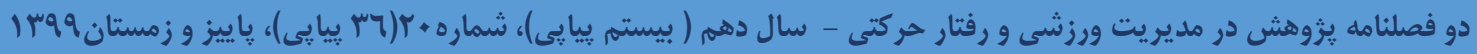

(ورزشكاران، والدين و مربيان) (اكتشافى) و بررسى رفتارها و نخرشهايى كه ورزشكاران و ديدگاههايى كه مربيان و والدين در اين زمينه دارند (توصيفى) بوده است. در اين يزوهش با توجه به هدف مطالعه، شركت كنندگان بر اساس نمونه كيرى هدفمند و از بين كودكان و نوجوانان ^ تا ما سال در شهر اصفهان كه به ورزش واليبال مى يرداختند و والدين

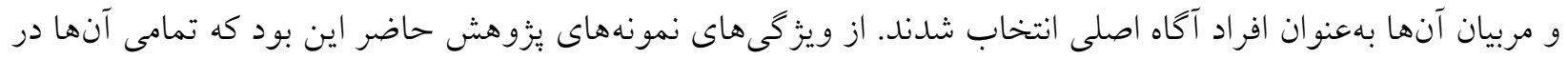
رشتهُ ورزشى جديد تمرين مى كردند و حداقل قبلاً در يك نوع فعاليت به ورزش يرداخته و آن را ترى كرده بودند.

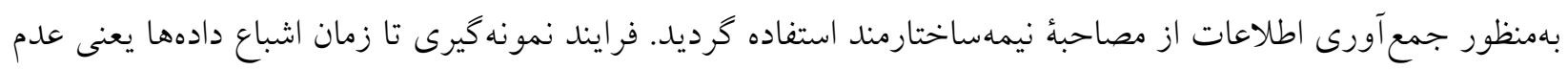
استخراج و ظهور مفهوم جديد از دادهها ادامه بيدا كرد. درنهايت از rا ا ورزشكار كودى و نوجوان، هشت والد (سه مادر و ينج يدر) و ينج مربى مصاحبه به عمل آمد. براى دستيابى به تجربيات مختلف سعى شد مشاركت كنند گان ازلحاظ ميزان و طول مدتزمان انجام ورزش باهم متنوع باشند. ويزگىىهاى جمعيت شناختى مشاركت كنندكان در جدول إنهاصه

\begin{tabular}{|c|c|c|}
\hline تعداد & ويز گیىها & مشاركت كنند گان \\
\hline & محدوده سنى & كودى و نوجوان \\
\hline 0 & 9 تا سا سال & \\
\hline v & عا تا \1 سال & \\
\hline & مدت ورزش & \\
\hline 1 & كمتر از r سال & \\
\hline 7 & r تا r سال & \\
\hline 0 & بيشتر از r سال & \\
\hline & محدوده سنى & والد \\
\hline$\varepsilon$ & rع سال و بالاتر & \\
\hline$\varepsilon$ & كمتر از بع سال & \\
\hline & محدوده سنى & مربى \\
\hline$r$ & زير •r سال & \\
\hline r & بالاى •r سال & \\
\hline & طول مدت مربيخرى & \\
\hline r & بالاى ه سال & \\
\hline$r$ & زير 0 سال & \\
\hline
\end{tabular}




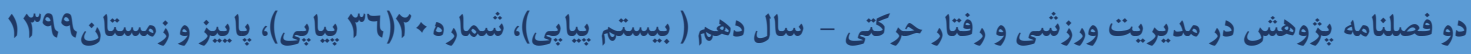

بهمنظور جمع آورى اطلاعات از مصاحبهُ نيمه ساختارمند به دليل انعطاف يذير بودن و عميق بودن و همجنين ساز كارى با ساير روشهاى تحليل دادهها (مثل نظريهٔ زمينهاى، يديدارشناسى تفسيرى) استفاده شد. براى شروع يزوهش ابتدا متن

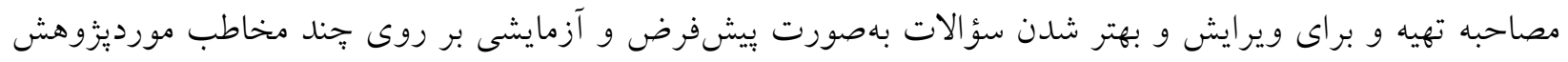
قرار كرفت. يس از تأييد اعتبار سؤالات توسط صاحبنظران اين حوزه (اساتيد درس روش تحقيق كه سابقهُ انجام بزوهش كيفى به اين شيوه داشتهاند)، متن مصاحبهُ اصلى تنظيم شد و مورداستفاده قرار كرفت. يس از آشنايى محقق با روش

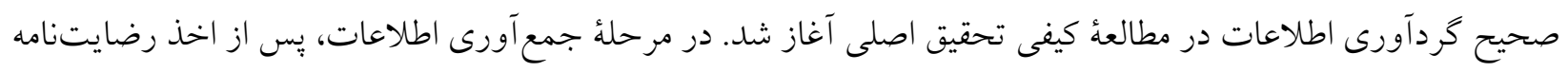
با ورزشكاران، مربيان و والدين آنها بهصورت جداكانه و انفرادى مصاحبه شد. مدت هر مصاحبه بين ·r تا •ع دقيقه متغير بود. مصاحبهها بهصورت تكى نفره انجام شد و شركت كنندگان در يُزوهش آزاد بودند كه در هركجاى مصاحبه از ادامهُ آن انصراف دهند و يا به هر دليلى از يزوهش خارج شوند. برخى از سؤالات مصاحبه كه از كودكان و نوجوانان يرسيده شد بدين شرح بود: جه عواملى باعث شد به سراغ ورزش بيايد؟ دليل اينكه ورزش قبلىتان را ترك كرديد جهه بود؟ جه اتفاق و يا عواملى در اين مكان بيش به ياد شما اينجا را هم ترك مى كنيد؟ به نظر شما جرا بعضى افراد ورزش

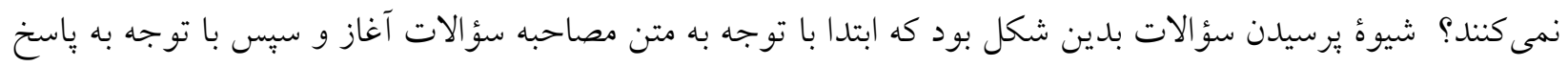
مصاحبهشوند كان بعضاً سؤ الاتى نيز در جلسهُ مصاحبه طراحى مىشد تا از آن طريق تمام ابعاد و جوانب سؤالات يزوهش يوشش داده شود. تمام مصاحبه ها با موافقت شركت كنند گان و بهوسيلهُ ضبطصوت و ميكروفون ضبط شد. بعد از اتمام مصاحبه، يس از گوش دادن جناينباره، مصاحبهها بهصورت متن بيادهسازى شد. براى تجزيهوتحليل دادهها از تحليل محتواى كيفى استفاده شد. اين روش بهمنظور تفسير ذهنى محتواى دادهاى متنى به كار مىرود. به كمك اين شيوه مىتوان درونمايهها و الخوهاى ينهان مطالعه را از درون محتو اى دادههاى حاصلشده از مشاركت كنند گان آشكار ساخت؛ جر اكه در اين روش از طريق فرايند طبقهبندى نظاممند، طبقات و درونمايهها مورد شناسايى قرار مى گيرد (·r). بدين ترتيب

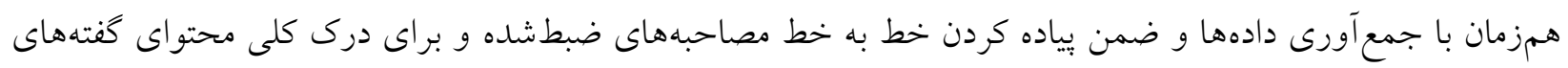

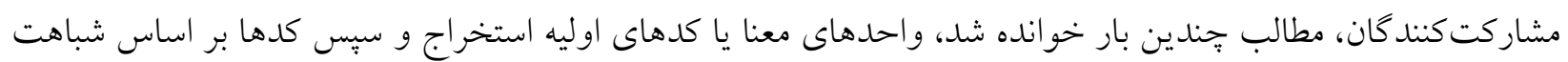

طبقهبندى گرديد و درنهايت درونمائُ اصلى و طبقات آن به دست آمد. بهمنظور تضمين باوريذيرى از روش بازبينى اعضاء استفاده شد. در اين راستا ابتدا مفاهيم و شاخصهاى استخراجشه توسط صاحب نظران اين حوزه مورد بازبينى قرار گرفت. ايشان دسترسى كامل به مصاحبهها و مضامين اصلى استخراجشده داشتند. يُ از تكميل كدكذارى اوليه از آنها خواسته شد تا ارتباط بين مضامين استخراجى و تفسيرهاى صورت كرفته بر مبناى آن و معرف بودن اين تفاسير و مضامين را بازبينى كند. درنهايت اين بازبينى منجر به يرسش و ياسخ بين نخارنده

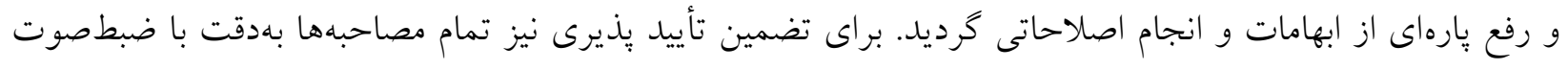
ثبت و به همان دقت بهصورت متن بيادهازى شد. علاقهمندى يزوهشخران به موضوع موردمطالعه، تماس درازمدت با 


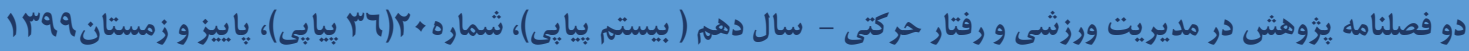

دادهها، و هم:جنين تلاش براى كسب نظرات ديخران در اين زمينه از ديخر عوامل تضمين كننده قابليت تأييد بودند. استفاده از نمونه گيرى با حداكثر تنوع براى كمك بهتناسب يا انتقال يذيرى يافتهها نيز در مطالعه موردتوجه قرار گرفت.

يافتها

درونمائُ بازدارندگى انخيزشى بهعنوان موانع مؤثر بر عادت به انجام فعاليت ورزشى به دست آمد كه خود به دوطبقه بازدارندههاى مربوط به شخص و بازدارندهاى مربوط به محيط تقسيم شد. منظور از بازدارندههاى شخصى مواردى همجيجون استعداد نداشتن و بيشرفت نكردن، لذت نبردن، آسيبهاى ورزشى و منظور از بازدارندهاى محيطى نبود فرهنگ ورزشى؛ امكانات و مشكلات اقتصادى، حمايت نشدن و آينده نداشتن بود (ثكل I ). در جدول r كدهاى مربوط به هر طبقه آورده شده است. مجموع اين موارد حاكى از آن بود كه در كودكان و نوجوانان به دلايل محيطى و شخصى عادت به انجام ورزش شكل نمى كيرد.

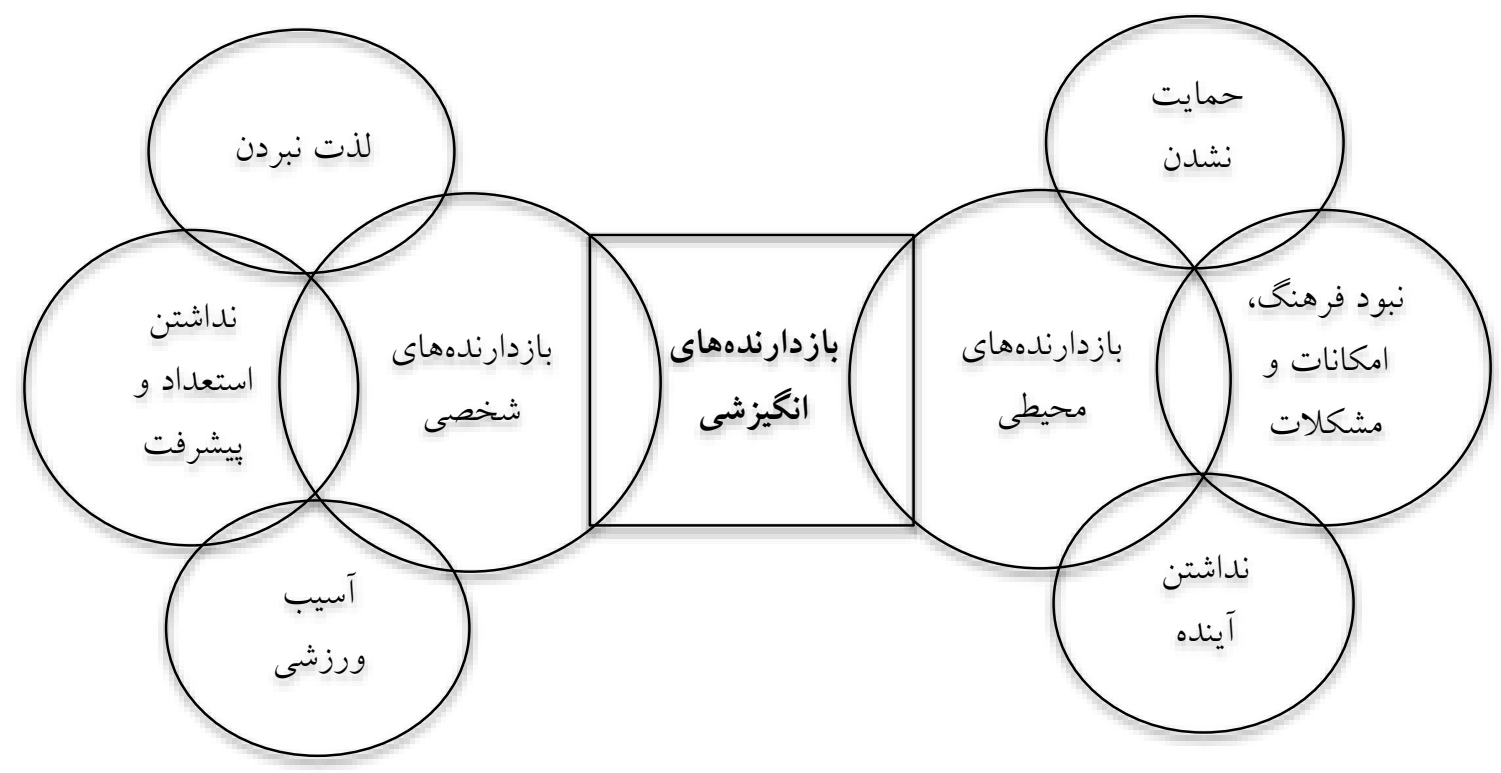

شكل ا. زير طبقات بازدارندهاى انخيزشى (درونمايئ اصلى)

در اين قسمت بعضى از نقلقولهاى مربوط به مصاحبههاى كودكان و نوجوانان آورده شده است: مانع عدم لذت و هيجان يكى از مواردى بود كه به دفعات توسط مصاحبهشوندگان به آن اشاره شد. ورزشكارى كه ورزش كاراته را ترى كرده و به واليبال روى آورده دربارهُ علت اين اقدام جنين مى گويد. تمريناتش خيلى سخت بود تو يه مسابقه هم رفتم و باختم و ازنظر روحى به هم فشار اومد براى همين ولش كردم 


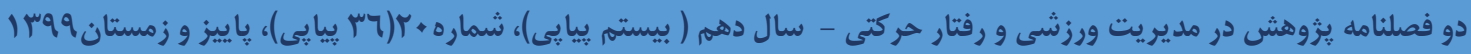

جدول r. درونمائُ بازدارندههاى انحيزشى و طبقات مربوط به نتايج حاصل از تحليل محتو اى مصاحبهها

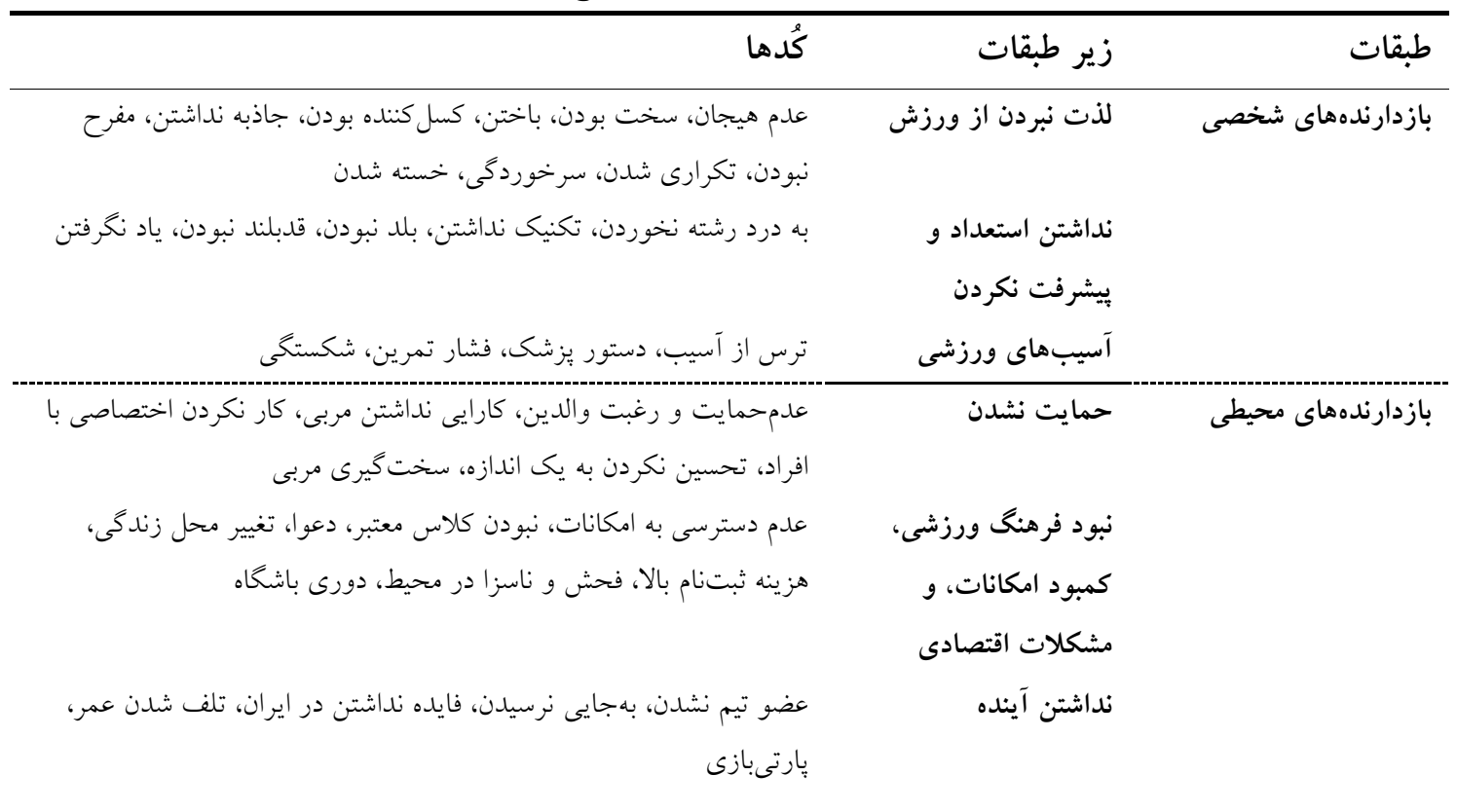

قوانين و ساختار رشتهُ ورزشى خاص و در نتيجه فشار و تنش زياد حاصل از تمرين نيز عاملى براى خروج از ورزش بود. ورزشكارى علت اينكه بعد از جندين سال ورزش تكواندو را ترك كرده جنين بيان مى كند: من اول به مدت \& سـال تكواندوكار كردم. بعد \& سـال فكر كردم كه به درد/ين رشـته نمى خورم.من از اين رشـته

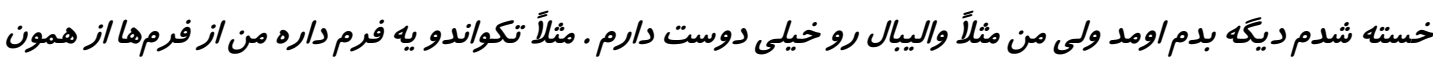
اول خوشم نميومد (مصاحبه شماره ع؛ سا ساله).

عدم كارايى مربى و عدم توجه به توانايىهاى فردى عاملى براى ترى ورزش از سوى ورزشكار ديخرى بود:

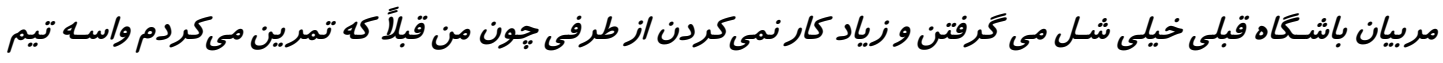

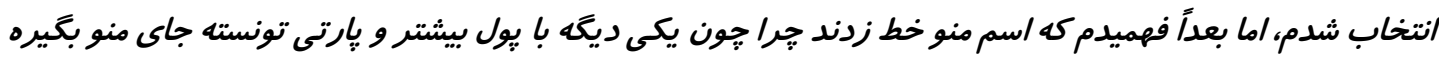

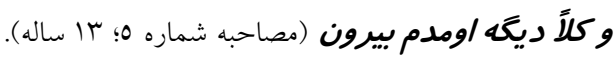
همين ورزشكار عضو تيم شدن را يكى از ملاكهاى اصلى براى ادامهُ ورزش خود مى داند و در ياسخ به اين سؤال كه اكر عضو تيم نشود جֶه مى كند، جنين مى گويد: ناراحت ميشم اكه /ينهمه تلاش كرده با شم خيلى ناراحت ميشم. ولى اكه بدونم كلاً به درد تيم نمى خورم نمى مونم، جون معتقدم كه وقت تلف كردنه و مى جسبم به درسم. (مصاحبه شماره 0؛ זا ساله) آسيب ديدن و فشار تمرين عامل ديخرى براى ترى مكرر ورزش از جانب ورزشكارى ديخر بودي: خوب من تو هر رشتهاى ميرم تجربه مى كنم بيينم جه جوريه؛ تو هر رشنه آدم يه تجربه دا شنته با شه بد نيست. مثلاً

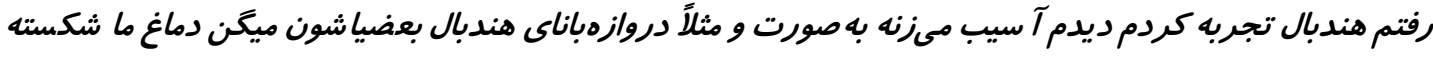




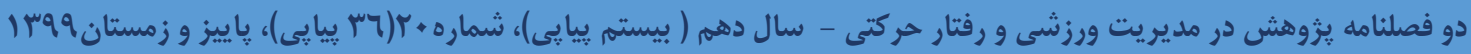

و كلاً منم دراينباره آدم ترسويى هستم و مىترسم براى همين /ومدم بيرون. شنا كه رفتم، شنا واقعاً رشنئ سختيه و

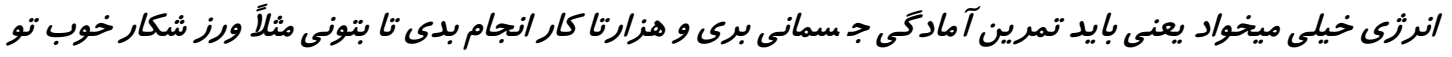

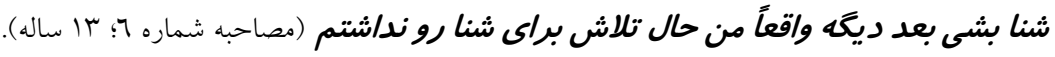

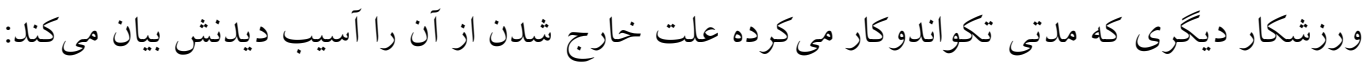
شما اكر مى بينى توان/ينرو دارى برى تكواندو ضربه بخورى وجيزيت نشه برو./ما من رفتم ٍام شكست ديكه ادامه ندادم. (مصاحبه شماره V؛ ع سال). ورزشكار ديخرى علت تغيير ورزشش را نبود امكانات بيان مى كند: من كلاس جهارم بسكتبال كار مىكردم ولى كلاس بنججم مدرسه مون سبد نداشت ديگه /دامه ندادم. (مصاحبه شماره 1 10 10 ساله).

ورزشكارى علت عدم علاقه و ترى فوتبال را آسيب و علاقه به واليبال را عدم آسيب ديدن بيان مى كند: جون فوتبال خيلى آسـيب مىزنه. جون يه بار تفريحى رفتم فوتبال آسـيب ديدم. واليبال رشـتهاى نيسـت كه به آدم

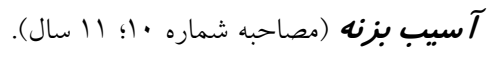
ورزشكار ديخرى علت اينكه به سمت فوتبال و بسكتبال نرفته را عدم توانايى و استعداد اوليه بيان مى كند: جون تاوَن قد و جثه بلندى دارند و من نداشتنم، تو فوتبال هم جون تكنيك ندارم (مصاحبه شماره إ؛ 17 سال). ورزشكار ديخرى علت ترى ورزشش را تغيير مكان زندكى و هزينههاى زياد باشگاه عنو ان مى كند: بدرم كفت كه ورزش خوبه. اول بسكتبال مىرفتم و م سال هم رفتم و دوست دا شتم. بعد مكانش عوض شد و بايد

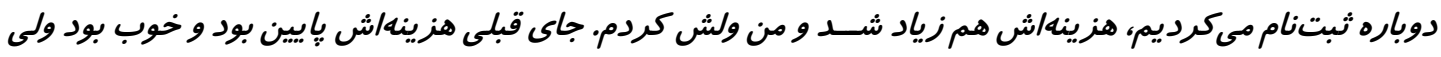

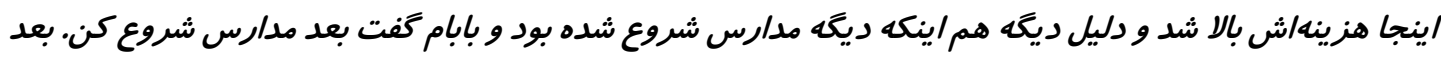

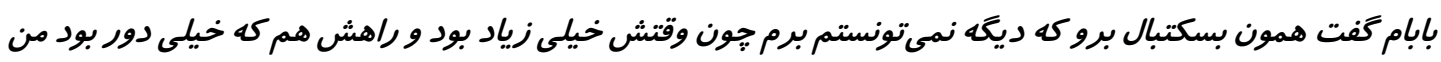

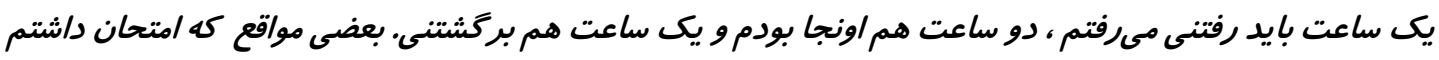

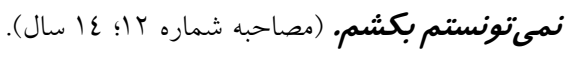
بعضى از نقلقولهاى مربوط به والدين در اين قسمت عنوانشده است: والدى در مورد اينكه تهرا فرزندش ورزش شنا را ترك كرده را عدم هيجان و لذت بيان مى كند:

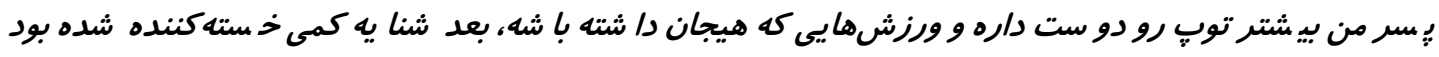

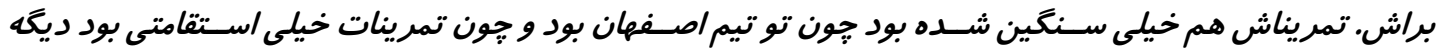
بىانكيزه شده بود براى شنا. يعنى رفتوبرگشت مرتب تو شنا خيلى براش خسنه كننده شده بود. (مصاحبه شماره )؛

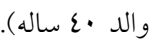

والد ديخرى در مورد اينكه جحرا از علاقهُ فرزندش به فوتبال سرباز زده و او را به سمت واليبال هدايت كرده را آسيبزا بودن ورزش فوتبال بيان مى كند: من خيلى از فوتبال به دليل محيطش خوثــم نمى آ مد وخيلى به فوتبال تشــويقش نمىكردم. يكى از دلايلى كه

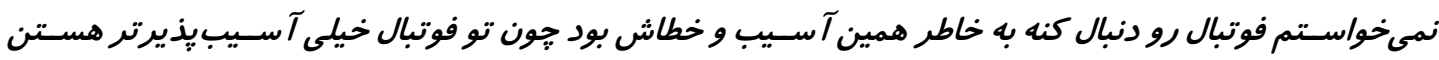




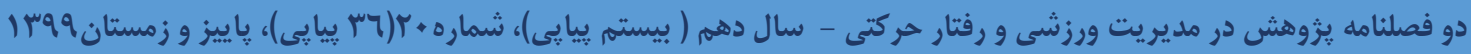

بجه ها و بجه من هم يكسى دو بار دست و پإش آسيب ديد. (مصاحبه شماره آو والد .ع ساله). والد ديخرى درباره اينكه خرا فرزندش باوجوداينكه در شنا موفق بوده او را خارج كرده عدم توجه به استعداد و توانيى

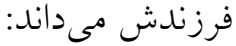

يه مقدار ديدم اونجا بارتى بازى /ست براى انتخابى كشورى ديگه كشيدمش كنار وآوردمش واليبال (مصاحبه شماره ז؛

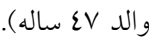

همين والد دربارهُ اينكه جرا فرزندش را از زيمناستيك خارج كرده عدم ييشرفت بيشتر و نبود امكانات مناسب مى داند:

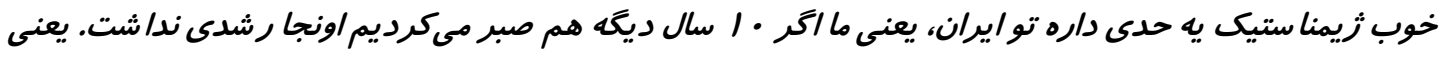
يه بجه • إ ساله تواوكراين خيلى زسبت به ما تبحر داره، يعنى ما حرفى وا سه كفتن تو دنيا تو ثريمنا ستيك نداريم. شما فرض كنيد يه كلاسى باشيد مرتب همون جا بمونيد خوب سرخورده مىشويد. من حساب كردم كه ع ماه از سال

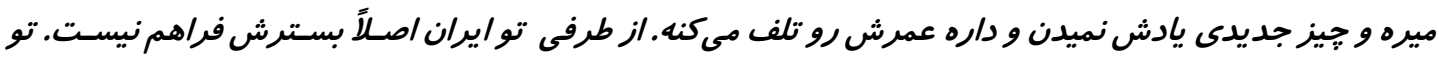

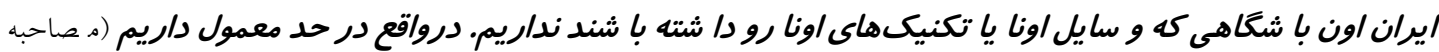
شماره ז؛ والد Vع ساله).

والدى ديخرى بعد مسافت و دورى باشخاه را عامل ترى فرزندش از ورزش مى مداند. يكى مسافت راه. تو كشـورهاى خارجى هر • • ه متر تا ا كيلومتر خونه شـون ورزشـاه دارند ولى تو/يران /ينطور نيست. (مصاحبه شماره 0؛ والد بع ساله).

همجنين او ورزش نكردن بعضى كودكان را به دليل مشكلات اقتصادى مردم مى داند:

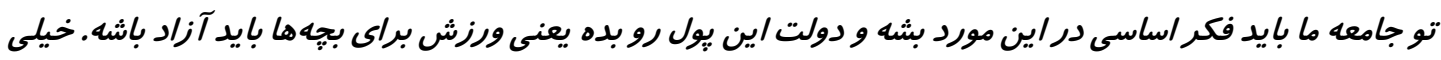
از بجه ها كه به ورزث روى نمى آورند به خاطر بیىيولى هست كه نمياند (مصاحبه شماره 0؛ والد بع ساله). مسائل مالى توسط برخى ديخر از والدين نيز اشاره شد: جايى كه قبلاً مىرفت خصوصى بود و هزينه/ش بالا بود، براى همين آمديم/ينجا. (مصاحبه شماره V؛ والد باع ساله)

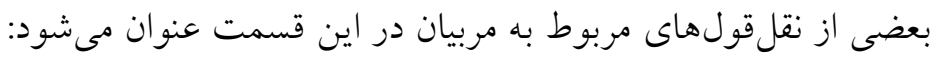

يكى از مربيان در مورد اينكه جرا بعضى افراد ورزش رو ترك كردهاند، علت را تغيير محل زندكى آنها مى آنداند: يه عده هم آمدند بنا بر شغل بدرشون /سبابكشى كردند و رفتند يا بعضى بجه هاى كوحيك شايد فكر مىكند توان انجام/ين ورزش روندارند (مصاحبه شماره آ؛ والد آب ساله). مربى ديكرى علت اينكه بعضى شاكردان بعد از مدتى ورزش را ترك مى كنند، را عدم توانايى و استعداد آنها مى داند: بعضى بجههاى كوجيك شا يد فكر مى كنند توان انجام/ين ورزش روندارند (مصاحبه شماره ع؛ مربى حr ساله). مربى ديخرى علت بىانخيزه بودن بعضى بجهها را رفاه بيشازاندازه در محيط خانه مىداند: بيشتر بجه ها يیى كه انتيزه ندارند توى خانواده ها يیى هستند كه مفرحاند يعنى خانواده هر جيزى خواستند در اختيارشون كذاشتند و به همين خاطر تو خونه شادند. وقنى مياد باشكاه مى بينه يه جيزى هم ازش ميخوان، بعد تحت تأثير قرار

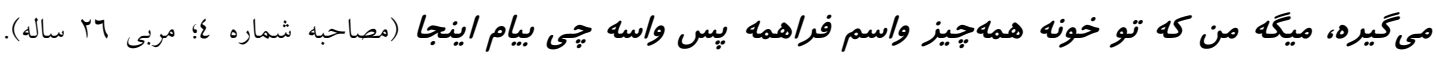




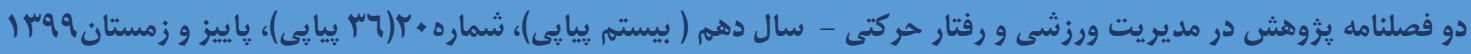

\section{بحث و نتيـجهـ كيرى}

نحوهُ مشاركت كودكان و نوجوانان در فعاليتهاى ورزشى مسئلة بيجيجيدهاى است كه عوامل زيادى در آن دخالت دارند. اينكه كودكان و نوجوانان جهه فعاليت ورزشى را انتخاب مى كنند، نياز به بررسى همهٔ عواملى دارد كه بهصورت مثبت (انكيزشى) و منفى (موانع) روى اين انتخابها تأثير مى كذارد. با توجه به اينكه كودكان و نوجوانان آيندهازان جامعه هستند، سلامت جسمانى و روانى آنها از اهميت بسزايى برخوردار است. هدف از اين يزوهش شناسايى ديدگاههاى ورزشكاران، والدين و مربيان راجع به موانع گرايش و عادت به انجام فعاليت ورزشى در بين كودكان و نوجوانان بود. نتايج تحقيق در دو مضمون تحت عناوين بازدارندهاى مربوط به شخص (استعداد نداشتن و بيشرفت نكردن، عدم هيجان و لذت از ورزش، فشار تمرين و آسيب ديدن) و بازدارندهاى مربوط به محيط (عدم دسترسى آسان به امكانات، مشكلات

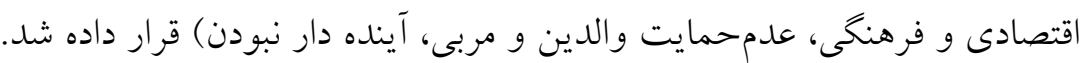
نتايج تحقيق نشان داد كه يكى از مهمترين موانع تداوم ورزشى در اين سن، نداشتن استعداد كافى و بيشرفت نكردن در هنخام يادكيرى مهارت است. بديهى است وقتى كه شخص متوجه شود بعد از مدتى حضور در محيط ورزش در يادكيرى مهارت جندان موفق عمل نكرده و بيشرفتى براى او حاصل نشده، انخيزه خود را ازدستداده و براى ادامهُ اين

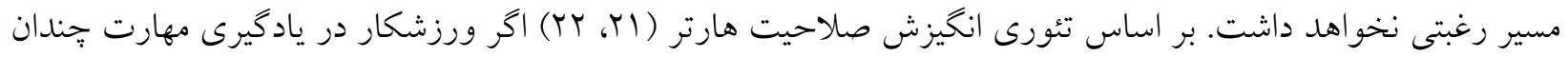
موفق عمل نكند در او انخيزش صلاحيت يايين و عاطفهُ منفى ايجادشده و باعث كناره گيرى او از ورزش مىشود. توصيه مى شود والدين ابتدا بر اساس علاقه و استعدادى كه فرزندانشان دارند آنها را به سمت آن ورزش رهنمون سازند تا كودكان و نوجوانان از آسيبهاى دلزدگى و كمبود از ورزش در امان باشند. از ديخر دلايل مىتوان به لذت نبردن از ورزش و برآورده نشدن نيازهاى روانى و احساس فشار بيشازحد هنگام فعاليت ورزشى اشاره كرد. اين عامل باعث مىشود ورزشكاران جوان با بى حوصلكى و رخوت تمرينات ورزشى را انجام دهند. مهمترين و اولين دليل كودكان براى شركت در فعاليتهاى ورزشى لذت، تفريح و سركرمى است. حفظ علاقهُ ورزشى و استمرار در ورزش نيز منوط به وجود اين بعد در فضاى ورزش است. آماروس نيز معتقد است لذتبخش بودن ورزش توجه كودكان را جلب مى كند (Tr). اين مسئلة نخست و مهم زمانى تحت الشعاع قرار مى گيرد كه مربيان و والدين بيشازحد بر اهميت انكيزههاى ديخر مثل بيروزى در مسابقات تأكيد ورزند. بديهى است توجه نكردن به لذت و تفريح به تجربهُ منفى و كمبود انكيزه ورزشكاران كودى و نوجوان منجر مىشود. كودكان به تيمها ملحق نمىشوند تا در كنارى

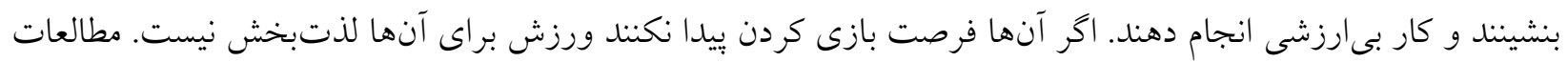
نشان مى دهد كه كودكان تمايل دارند تا در يك تيم بازنده بازى كنند تا اينكه در يك تيم برنده بهعنوان يكى از اعضاى تيم در اطراف زمين نشسته باشند. اكر آنها بازى نكنند خيلى سريع علاقهشان را از دست مى دهند. تجون با ورزش كردن در آنها احساس خوب ايجاد مىشود. آنها نياز دارند كه احساس ارزش كنند و شاد باشند. اما اكر آنها (دختران يا يّران) بلهور اتفاقى روى نيمكت بنشينند يا به دليل نياز تيم به برنده شدن از تيم كنار كذاشته شوند، كودك ممكن است احساس 


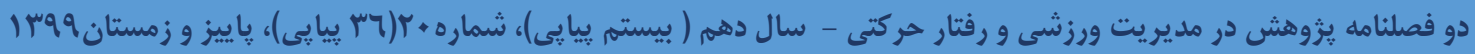

بى كفايتى و نيذيرفته شدن بكند. يكى از مشكلات در اين زمينه وجود مربيان ناكارآمد و فاقد تخصص لازم است كه با انجام تمرينات نامناسب تنها سبب دلزدكى و بى حوصلكى فرد هنخام ورزش مىشوند. حضور فعالتر افراد كار آزموده و كذراندن دورههاى تخصصى توسط افراد متقاضى و توجه به ابعاد روانى ورزشكاران جوان، مىتواند در جلب اعتماد كودكان و نوجوانان مفيد باشد.

يكى ديخر از موانع، حمايت نكردن والدين از برنامه هاى ورزشى فرزندشان به هر شكل ممكن است. نقش بدر و و مادر در مشاركت ورزشى كودكان و نوجوانان بهطور جشم گيرى مىتواند متفاوت باشد. ازجمله تسهيل حضور ورزشكاران جوان در ورزش از طريق اقدام بهعنوان مربى، داور، مدير و يا مشاور، كمك به درك و تفسير كودى از تجربهُ ورزشى

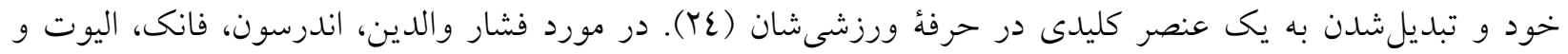
اسميت (Y0) بيان كردند، در مواردى كه فشار والدين افزايش يافته است كودكان كزارش كردهاند كه لذت و رضايت كاهش يافته است. والدين ممكن است باور داشته باشند كه اظهار ناميدى در برابر عملكرد ضعيف كودى، انخيزهُ او را براى بهبود عملكرد ارتقاء مى دهد، اما از ديدكاه كودكان، فشار والدين حتى بهدرستى مىتواند نتيجهُ معكوس داشته باشد و ممكن است باعث كاهش لذت و انخيزه كودكان شود. علاوه بر اين فشار بيشازحد والدين با تأثير منفى بر درى ورزشكاران ارتباط دارد. بر اين اساس اگر ما مىخواهيم تا كودكان را از همان سالهاى اوليه در تمرينات ورزشى در گير كنيم و استعدادهاى آنها را شكوفا كنيم، ضرورى است تا محيط خوبى كه در مهرومومهاى شكل گيرى لازم است تعريف كنيم و والدين در اين فرايند نقش حياتى دارند (T). مكانيسمى كه والدين مىتوانند بر فعاليت بدنى كودكان و نوجوانان اثر بحذارند به دو صورت مستقيم و غيرمستقيم بيشنهاد شده است. مستقيم از طريق تشويق كلامى و تقويت مثبت، حملونقل به و از فعاليتها، تماشاى فعاليتها، شركت همراه با فرزندانشان و غيرمستقيم از طريق الكو شدن يا بهاحتمالزياد، تعامل اين دو باهم (TV). تأكيد بيشازحد روى ييروزى، يك مشكل اساسى در ورزش كودكان و نوجوانان از جانب والدين است. بنابراين يكى از وظايف عمدهُ مربيخرى، كمك به بدران و مادران در تفهيم ورزش بهعنوان برآورنده نيازها و توانايىهاى جسمى فرزندانشان است. شادى بازى با همسالان، توسعهُ آمادكى جسمانى، يادكيرى مهارتها، بهكار گيرى حداكثر توان جسمى، لذت بردن از هيجانات در ورزش و توسعهُ خودباورى، تعدادى از مزاياى يرداختن به ورزش است، كه اغلب از جانب والدين، به دليل اينكه در اين فعاليتها بردوباخت مطرح نيست، موردتوجه قرار نمى گيرد. يكى از روش هاى مؤثر براى جلب حمايت و اعتماد والدين، بركزارى ديدارهايى بين والدين، ورزشكاران

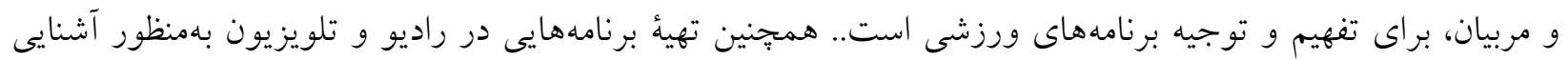
افراد با فوايد ورزش مىتواند در تغيير نخرش والدين در اين زمينه مؤثر باشد. همجنين سازمانهاى فرهنگساز جامعه نظير آموزشويرورش و صداوسيما بايد كامهايى را در جهت اصلاح ديد افراد نسبت به ورزش بردارند. در بعد ديخر عواملى نظير هزينهاى انجام فعاليت ورزشى و بهتبع آن وضعيت اقتصادى خانواده و همجنين اولويت قرار داشتن درس و ترس از افت تحصيلى مانعى جهت حضور مداوم در فعاليتهاى ورزشى است. مسائل مالى بهعنوان 


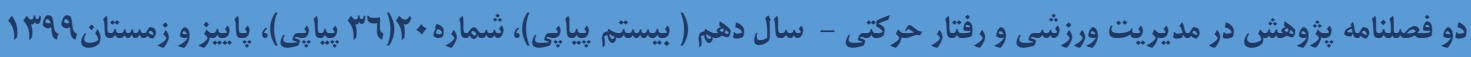

يكى از موانع ورزش و فعاليت بدنى در برخى مطالعات گزارش شده اند (YN). شايد تخفيف به كودكان و نوجوانان توسط سالنها، كاهش حق اجارهُ سالنها و نشان دادن افراد موفق ورزشى كه در تحصيل نيز موفق بودهاند و ورزش خللى بر درس آنها وارد نكرده است از سوى رسانهها مىتواند راهخشاى اين موانع باشد. ازجمله مشكلات ديخر در اين زمينه نبود امكانات و يا عدم دسترسى آسان به مكانهاى ورزشى بود. اين يافته مشابه يُزوهش هاى قبلى در اين زمينه بود. ساليس و همكاران (Y9) عنوان كردند كه دسترسى به فضاهاى ورزشى به طور قابل توجهى با سطح فعاليت بدنى كودكان و نوجوانان مرتبط است. در يزوهشى ديخر تراست و همكاران (•r) عنوان كردند كه دسترسى به برنامههاى فعاليت بلدنى يكى از قوىترين ييشبينى كنندها از ميزان فعاليت بدنى در ورزشكاران جوان است. اين مسئله موجب مىشود كه كودكان و نوجوانان به دليل عدم دسترسى به باشگاه از ورزش كردن صرفنظر كنند و يا به سراغ ورزشى بروند كه به آن علاقه ندارند كه در حالت دوم بازهم به دليل بىعلاقكى احتمال تداوم ورزش اندك خواهد بود. بديهى است مسيرهاى دور نيز

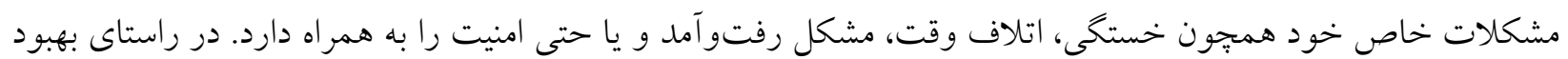
اين وضعيت حمايت از ساخت اماكن ورزشى و مكانيابى مناسب بهمنظور ساخت سالنهاى ورزشى در مركز شهر و فراهم نمودن وسايل حملونقل مناسب به فضاهاى ورزشى به كونهاى كه در دسترس عموم مردم باشد كار گشا خواهل بود. بعضى از كودكان و نوجوانان نيز كه به ورزش فعاليت داشتهاند به دليل تغيير محل زندگىشان از ورزش خارج شدهاند. در اين راستا به خانو ادهها توصيه مىشود به ورزش بهعنوان يكى نياز مبرم و اساسى براى رشد و توسعهُ جسمانى، شناختى، اجتماعى و روانى فرزندانشان نخاه كنند و در هر موقعيتى شرايط لازم براى اين كار را براى آنان فراهم سازند.

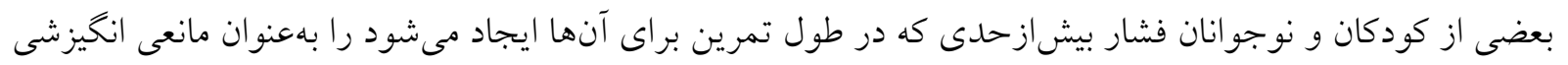
براى تداوم ورزشى خود برشمردند. اين مسئله از دو ديدكاه قابل بررسى است. در نخاه اول، شخص در رشتهُ ورزشى موردنظر استعداد لازم را ندارد و همين عدم استعداد باعث مىشود فشار بيشازحدى را جه ازنظر جسمانى و جهه ازنظر روانى در محيط ورزش تجربه كند. در حالت دوم مربى و يا فرد آموزشدهنده به دليل بى تجربكى و يا ناكار آمدى، فشار زيادى را در طول تمرينات بر روى ورزشكاران وارد مى كند و همين عامل باعث مى شود حتى افرادى كه در آن ورزش بـ مرنى استعداد كافى نيز دارند به دليل خستخى زياد ناشى از تمرين دلزده شده و حس بيزارى در آنها به وجود بيايد. مربيان بايد توجه كنند، كودكان و نوجوانان فعاليتهايى را دوست دارند كه خودشان آنها را برمى گزينند و حق انتخاب دارند يا در آن فعاليتها نيازمند حمايت، تشويق و مراقبت بيشتر مربيان خود هستند. بنابراين آكاهى از اينكه كودكان و نوجوانان با جه مقاصدى در فعاليتها شركت مى كنند مربيان را در انتخاب و تأكيد بر نوع فعاليتها و ارائهُ شرايط انخيزشى از طريق بررسى و مطالعهُ آنها يارى مىرساند. كيخان، اسبراى، هاروود و لاوالى ( آس) در يك مصاحبهُ نيمه ساختارمند، روى

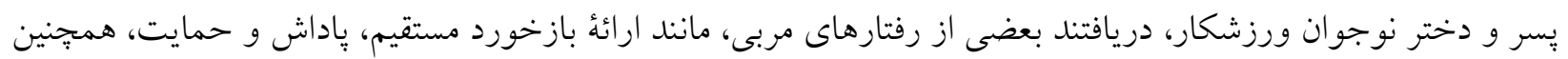
نمايش تحمّل و كنترل عاطفى هنگام تعامل با بازيكنان بهعنوان انخيزشهاى خاص تلقى مىشود. توصيه مىشود در محيط ورزش كودكان و نوجوانان با توجه به حساسيتهاى روانى و رشدى در اين سن از مربيان باتجربه و كار آزموده در ورزشي 
كودكان و نوجوانان استفاده شود. همجنين استفاده از تمرينات با توجه استعداد و توانايى هر فرد براى جلو كيرى از وارد آمدن فشار به فرد بيشنهاد مى گردد.

بهنظور بيشخيرى از تجارب منفى در ورزش كودكان و نوجوانان، سازمان دهند گان بايد جندين جلسات مشاورهاى در اين زمينه بركزار كنند، هم براى مربيان ورزش كودكان و نوجوانان و هم براى تمامى والدين كودكان و نوجوانان

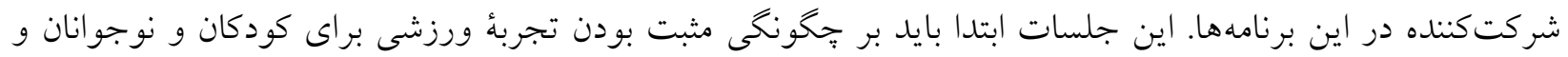

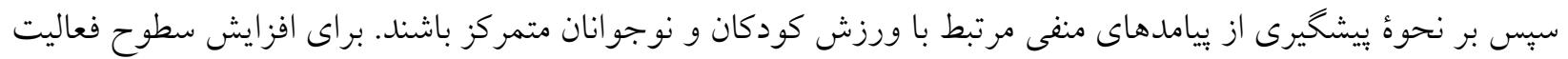

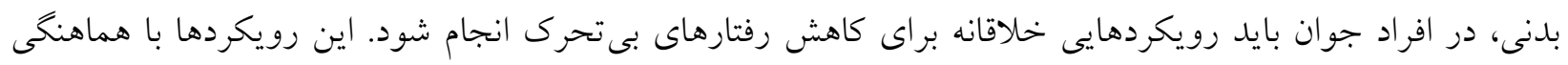

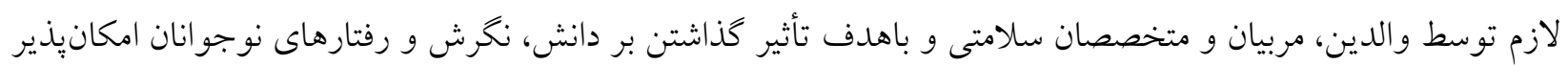
است با اين اميد كه عادات سالم در آنها شكل بخيرد و طول عمر بيشترى داشته باشند. تحقيقات نشان مىدهد كه عواملى

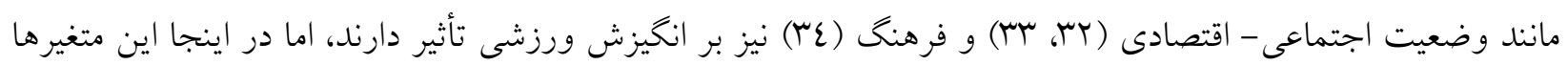
بررسى نشدند. بديهى است در تحقيقات آتى بايد اين متغيرها نيز موردتوجه قرار بخيرند. همجنين در اين يزوهش از

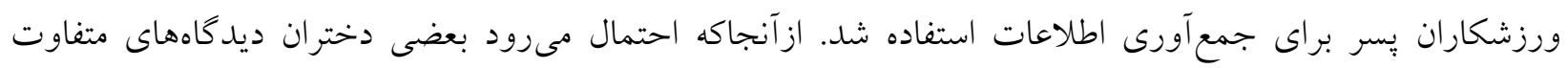

$$
\begin{aligned}
& \text { دراينباره داشته باشند، توصيه مىشود يزوهشى بر روى دختران، والدين و مربيان آنها نيز انجام كيرد. } \\
& \text { تشـكرّ و قدردانى } \\
& \text { بدينوسيله از كلية افرادى كه در اين يُزوهش نقش داشتند تشكّر و قدردانى مى شود. }
\end{aligned}
$$

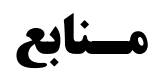

1. Eime RM, Young JA, Harvey JT, Charity MJ, Payne WR. A systematic review of the psychological and social benefits of participation in sport for children and adolescents: Informing development of a conceptual model of health through sport. Int $\mathrm{J}$ Behav Nutr Phys Act. 2013;10(98):1-21.

2. Raudsepp L, Viira R. Changes in physical activity in adolescent girls: A latent growth modelling approach. Acta Paediatrica. 2008;97(5):647-52.

3. Strong WB, Malina RM, Blimkie CJ, Daniels SR, Dishman RK, Gutin B, et al. Evidence based physical activity for school-age youth. The Journal of pediatrics. 2005;146(6):732-7.

4. Troiano RP BD, Dodd KW, Masse LC, Tilert T, McDowell M. . Physical activity in the united states measured by accelerometer. Medicine and science in sports and exercise. 2008;40(1):181-8.

5. Newton M, Duda JL, Yin Z. Examination of the psychometric properties of the perceived motivational climate in sport questionnaire-2 in a sample of female athletes. Journal of Sports Sciences. 2000;18(14):275-90.

6. Orlick TD. Children's sport-a revolution is coming. Canadian Association for Health, Physical Education and Recreation Journal. 1973;40:12-4.

7. Sagar SS, Lavallee D, Spray CM. Why young elite athletes fear failure: Consequences of failure. Journal of Sports Sciences. 2007;25(11):1171-84.

8. Weiss MR. Children's participation in physical activity: Are we having fun yet? Pediatric Exercise Science. 1993;5(3):205-10. 
9. Allender S, Cowburn G, Foster C. Understanding participation in sport and physical activity among children and adults: A review of qualitative studies. Health education research. 2006;21(6):826-35.

10. Hosseini SV, Anoosheh M, Abbaszadeh A, Ehsani M. Adolescent girls and their parents' perception of exercise habit barriers. Journal of Qualitative Research in Health Sciences. 2012;1(2):148-57 (In Persian).

11. Dixon JL. A study to investigate reasons for team inating or continuing sport participation in warrensburg middle schoo students. United State: Central Missouri State University; 2001.

12. Veitch J AL, Hume C, Ball K. . Children's perceptions of the factors helping them to be 'resilient'to sedentary lifestyles. Health education research. 2013;28(4):692-703.

13. Edwardson CL, Gorely T. Parental influences on different types and intensities of physical activity in youth: A systematic review. Psychology of Sport and Exercise. 2010;11(6):52235.

14. Horn TS, Horn JL. Family influences on children's sport and physical activity participation, behavior, and psychosocial responses. In: Tenenbaum G, Eklund RC, editors. Handbook of sport psychology. 3 ed: Wiley; 2007. p. 685-711.

15. Gould D, Feltz D, Horn T, Weiss M. Reasons for attrition in competitive youth swimming. Journal of Sport Behavior. 1982;5(3):155.

16. Sapp M, Haubenstricker J, editors. Motivation for joining and reasons for not continuing in youth sports programs in michigan. American Alliance for Health, Physical Education, Recreation and Dance National Convention, Kansas City, MO; 1978.

17. Anshel MH. Sport psychology: From theory to practice. 5th ed. London: Pearson; 2011.

18. Barzgari A, Mahdivand A, Zameni L. Educational courses physical education base of a specific structure of free activity. Roshd physical education. 2011;40(1):58-61. (In Persian).

19. Dishman R, Buckworth J. Increasing physical activity: A quantitative synthesis. Medicine and science in sports and exercise. 1996;28(6):706-19.

20. Hsieh H-F, Shannon SE. Three approaches to qualitative content analysis. Qualitative health research. 2005;15(9):1277-88.

21. Harter $S$, editor A model of intrinsic mastery motivation in children. Minnesota Symposia on Child Psychology. Hillsdale, NJ: Lawrence Erlbaum Associates; 1980.

22. Harter S. Effectance motivation reconsidered. Toward a developmental model. Human development. 1978;21(1):34-64.

23. Amorose AJ. Reflected appraisals and perceived importance of significant others' appraisals as predictors of college athletes' self-perceptions of competence. Research Quarterly for Exercise and Sport. 2003;74(1):60-70.

24. Holt NL, Knight CJ. Parenting in youth sport: From research to practice: Routledge; 2014.

25. Anderson JC, Funk JB, Elliott R, Smith PH. Parental support and pressure and children's extracurricular activities: Relationships with amount of involvement and affective experience of participation. Journal of Applied Developmental Psychology. 2003;24(2):241-57.

26. Sánchez-Miguel PA, Leo FM, Sánchez-Oliva D, Amado D, García-Calvo T. The importance of parents' behavior in their children's enjoyment and amotivation in sports. Journal of human kinetics. 2013;36(1):169-77.

27. Welk GJ, Wood K, Morss G. Parental influences on physical activity in children: An exploration of potential mechanisms. Pediatric exercise science. 2003;15:19-33.

28. Standage M, Duda JL, Ntoumanis N. A test of self-determination theory in school physical education. British Journal of Educational Psychology. 2005;75(3):411-33. 


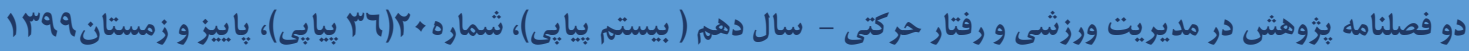

29. Sallis JF, Simons-Morton BG, Stone EJ, Corbin CB, Epstein LH, Faucette N, et al. Determinants of physical activity and interventions in youth. Medicine \& Science in Sports \& Exercise. 1992;24:248-57.

30. Trost SG, Pate RR, Saunders R, Ward DS, Dowda M, Felton G. A prospective study of the determinants of physical activity in rural fifth-grade children. Preventive medicine. 1997;26(2):257-63.

31. Keegan RJ, Harwood CG, Spray CM, Lavallee DE. A qualitative investigation exploring the motivational climate in early career sports participants: Coach, parent and peer influences on sport motivation. Psychology of sport and exercise. 2009;10(3):361-72.

32. Chen K-C, Jang S-J. Motivation in online learning: Testing a model of self-determination theory. Computers in Human Behavior. 2010;26(4):741-52.

33. Dacey M, Baltzell A, Zaichkowsky L. Older adults' intrinsic and extrinsic motivation toward physical activity. American journal of health behavior. 2008;32(6):570-82.

34. Vierling KK, Standage M, Treasure DC. Predicting attitudes and physical activity in an "atrisk" minority youth sample: A test of self-determination theory. Psychology of Sport and Exercise. 2007;8(5):795-817. 